\title{
Semantic Epistemology: Response to Machery
}

\author{
Michael DEVITT
}

Received: 1.4.2012

Final version: 1.4.2012

BIBLID [0495-4548 (2012) 27: 74; pp. 229-233]

ABSTRACT: Machery argues: (1) that "philosophers' intuitions about reference are not more reliable than lay people's -if anything, they are probably worse"; (2) that "intuitions about the reference of proper names and uses of proper names provide equally good evidence for theories of reference". (1) lacks theoretical and empirical support. (2) cannot be right because usage provides the evidence that intuitions are reliable.

Keywords: methodology; theory of reference; experiments; linguistic intuitions; linguistic usage; corpus; elicited production; Expertise Defense; bias.

RESUMEN: Machery defiende que (1) "las intuiciones de los filósofos sobre la referencia no son más fiables que las de los legos — si acaso, serían peores"; (2) las "intuiciones acerca de la referencia de los nombres propios y los usos de los nombres propios ofrecen evidencia de igual valor para las teorías de la referencia". (1) carece de base empírica o teórica. (2) no puede ser correcta, puesto que el uso ofrece evidencia de que las intuiciones son fiables.

Palabras clave: metodología; teoría de la referencia; experimentos; intuiciones lingüísticas; usos lingüísticos; corpus; producción solicitada; Defensa de los Expertos; sesgo.

The standard methodology of the theory of reference appears to be one of consulting the referential intuitions of philosophers. In "Semantics, cross-cultural style" (2004), Edouard Machery, Ron Mallon, Shaun Nichols, and Stephen Stich ("MMNS") base a challenge to this methodology on the results of an experimental test of the referential intuitions of some folk. This provocative paper has stimulated many others. My "Whither Experimental Semantics?" (2012) is one. Its main conclusion is that we should use the following as evidence for the theory of reference:

(A) philosophers' referential intuitions, both informally and, occasionally, scientifically gathered; (B) the corpus, both informally and scientifically gathered; (C) elicited production; and, occasionally, (D) folk's referential intuitions. The most novel part of this is (C) and that is where most of the experimental work should be. $(2012,33)$

Machery and Stich have urged a very different methodology:

that philosophers of language should emulate linguists, who are increasingly replacing the traditional informal reliance on their own and their colleagues' intuitions with systematic experimental surveys of ordinary speakers' intuitions. $(2012,495)$

I think that this methodology is as wrong for the philosophy of language as I have earlier argued it is wrong for linguistics (2006). My main conclusion is at odds with it in at least two ways. (1) Insofar as we should gather referential intuitions, I argue that we should prefer those of philosophers and only occasionally attend to those of the folk: we should prefer (A) to (D). (2) I argue against the apparently total reliance on the indirect evidence of referential intuitions, whether those of philosophers or folk, and emphasize the greater evidential value of the direct evidence provided by the linguistic reality that 
these intuitions are about: we should test theories of reference against linguistic usage: I emphasize (B) and (C).

Machery's "Semantic Epistemology: A Brief Response to Devitt" (this issue) ${ }^{1}$ argues against both (1) and (2). Countering (1), he claims that "philosophers' intuitions about reference are not more reliable than lay people's - if anything, they are probably worse". Countering (2), he claims that "intuitions about the reference of proper names and uses of proper names provide equally good evidence for theories of reference."

I shall take these bold counter-claims in turn but must, through lack of space, pass over some aspects of Machery's discussion.

My view that we should prefer the referential intuitions of philosophers to those of the folk is an instance of what has become known as "the Expertise Defense" against MMNS's conclusions. Machery characterizes this as follows:

The Expertise Defense is, roughly, the view that experimental findings about lay people's intuitions do not bear much (if at all) on philosophical controversies because lay people's intuitions are less reliable than philosophers'.

My theory of intuitions leads to a rather more nuanced view of referential intuitions than this. The view is that the more expert a person is about reference, the wider his range of reliable referential intuitions. But the theory does not lead to the view "that folk intuitions should never be sought nor that they provide no evidence" $(2012,20)$. Machery's criticisms of the Expertise Defense are aimed much more at his characterization of it than at mine.

Before considering these criticisms, it is worth noting that the fate of the Defense means much more for Machery's methodology than for mine. For, if the Defense were true, he would be left with no basis for his emphasis on the experimental testing of folk intuitions. In contrast, if the Defense were false, my emphasis on testing usage rather than intuitions would be left untouched. I would simply have to give up the preference for philosophers' intuitions when it comes to testing intuitions (2012, 31-2).

In objecting to my Expertise Defense, Machery claims: "Devitt does not explain in any detail how philosophers' theories of reference enhance the reliability of their intuitions." I find this near-repetition of an earlier criticism puzzling, for I take myself to have already addressed it adequately $(2012,18-20,22-3)$. As I point out, the idea that theorizing in an area improves intuitions about that domain "falls out" of the theory of intuitions that I propose. I claim that intuitions

are empirical theory-laden central-processor responses to phenomena, differing from many other such responses only in being fairly immediate and unreflective, based on little if any conscious reasoning. $(2006,103)$

So, we should prefer the referential intuitions of philosophers because they have better background theories and training than the folk. What "details" does Machery want? I call my theory "the Modest Theory" of intuitions because it makes do with cognitive states and processes we are already committed to. There is nothing special to the role of theory in the forming of referential intuitions: theory plays the same sort

${ }^{1}$ All unidentified references are to this work.

Theoria 74 (2012): 229-233 
of role here that it plays in forming empirical opinions generally. We must wait on progress in epistemology for details here as elsewhere.

Machery has two particular reasons for thinking that I need to say more. First, he notes the extent of disagreement among theorists of reference. Now certainly agreement among theorists in a domain should increase confidence in their intuitions about that domain. Still, the prediction is that a background of training and theorizing in the domain should alone improve the intuitions. And, as I point out, it is striking that description theorists of names accepted Kripke's referential intuitions that counted against their theories $(2012,22)$.

Second, Machery emphasizes that "even when scientists have better theories than lay people, their intuitions are not always improved by these theories." I agree. And so I agree that we need to test my predicted improvement in referential intuitions. I indicate, in effect, how we have already done so by combining MMNS's very own results with informal tests of usage (2012, 23-5, 27-9), and how we could do so better by combining those results with formal tests of usage (2012, 29-30). Wesley Buckwalter and I (2011) have started the formal testing. Very briefly, MMNS show that the folk's intuitions are less Kripkean than philosophers' in Gödel cases, and independent tests of usage are showing that Kripke is right about reference. The Expertise Defense is thus being confirmed.

Machery raises a concern about philosophers' intuitions being biased by their theories: "When scientists identify a possible bias, they do not simply shrug and mutter, 'C'est la vie!'”. He writes as if I disagree, but I don't. I have quite a bit to say about countering the risk of bias. But, contrary to what Machery claims, this risk does not undermine my Expertise Defense and does not warrant much of a role for folk referential intuitions $(2012,21-2)$ :

There is a point to surveying folk rather than more expert philosophers only in the rather unlikely circumstance that there is no other way of guarding against theoretical bias (or if there is concern that the folk have a referentially different idiolect). $(2012,32)$

My Expertise Defense rests, of course, on my theory of intuitions. So, one might resist the defense by rejecting the theory. MMNS do reject it but, as I point out, they do so by appealing to authority not argument (2012, 20-1). Or one might also resist by arguing for a different theory of intuitions. But on this matter Machery continues the MMNS tradition of silence.

The need for a theory is particularly pressing given Machery's concern about bias. The legitimate concern is that false parts of a theory of language held by linguists or philosophers may lead them to false intuitions. It is odd indeed to combine that concern with the claim that true parts of a theory do not lead them to true intuitions. Yet Machery's rejection of the Expertise Defense does seem to commit him to that combination (assuming, as Machery rightly does, that the theories of linguists and philosophers have more true parts than those of the folk). What theory could justify this combination? Perhaps the voice-of-competence theory (a speaker's referential intuitions are a product of her linguistic competence)? But Machery does not offer the theory as justification. And, I argue, the theory is false (2012, 14-21). 
In light of this, let us compare the epistemic status of the Expertise Defense with Machery's bold first counter-claim: "philosophers' intuitions about reference are not more reliable than lay people's - if anything, they are probably worse".

Theoretical support. Machery demands that I supply details of how the Defense could be true. I offer a plausible general theory of intuitions that supplies as many details as one should expect. In contrast, though Machery offers two theoretical considerations against the reliability of philosophers' intuitions - bias and idiolect difference - he offers no theoretical support for the view that any of these intuitions, including the folk's, have any reliability at all. Where are his details?

Empirical support. Machery is right to demand this support for the Defense. And that support is coming, in part from usage. But where is the empirical support for Machery's counter-claim? With one important exception, the experiments he cites do not even pretend to provide evidence of the degree of reliability of anyone's referential intuitions. The exception is the experiment discussed in Machery et al. 2009. It can be argued that this experiment indirectly provides evidence from usage that folk intuitions about Gödel cases are reliable. Setting aside my many doubts about this argument, I make just one point. The experiment does not show that folk intuitions are as reliable as those of philosophers, let alone probably better. So it does not support Machery's bold claim.

This brings us to Machery's second bold counter-claim. He is of course right to be concerned about the reliability of referential intuitions. Where could we find evidence of this reliability? As with the reliability of any intuition about anything, we find evidence in the reality that the intuition is about. So, in this case, we look to linguistic reality, exemplified in linguistic usage. Yet consider Machery's counter-claim: "intuitions about the reference of proper names and uses of proper names provide equally good evidence for theories of reference." How could the intuitions provide evidence as good as actual usage given that their status as reliable evidence at all depends on the evidence of usage?! And what are we to make of the related claim that the intuitions "provide evidence about reference that is as reliable as the use of proper names"? There can be no comparable issue of reliability here.

Consider two analogous claims. "Intuitions about living things and the actual properties of living things provide equally good evidence for biological theories." "Economic intuitions provide evidence about the economy that is as reliable as economic behavior." There is something very wrong about Machery's claims.

In conclusion, my point is not that folk intuitions would never be good evidence for a theory of reference. It is rather that that they are seldom worth the trouble of gathering. If one wants intuitions, the philosophers' are easier to gather and generally preferable anyway. But the best, and most direct evidence, is from usage. That from the corpus is not really that hard to find $(2012,27-8)$. And, when it comes to experimenting on the folk, eliciting their usage is evidentially much better, and probably not practically more difficult, than eliciting their intuitions (2012, 29-31). 


\section{REFERENCES}

Buckwalter, W. and M. Devitt. 2011. Testing theories of reference: Usage vs intuitions. Metro Experimental Research Group, City University of New York Graduate Center, invited presentation 11 February 2011

Devitt, M. 2006. Ignorance of language, Oxford: Clarendon Press.

—. 2012. Whither experimental semantics? Theoria 27/1: 5-36.

Machery, E., R. Mallon, S. Nichols, and S. P. Stich. 2004. Semantics, cross-cultural style. Cognition 92: B1B12.

-, Olivola, C. Y., and M. de Blanc. 2009. Linguistic and metalinguistic intuitions in the philosophy of language. Analysis 69: 689-694.

-, and S. P. Stich. 2012. The role of experiments in the philosophy of language. In Routledge companion to the philosophy of language, ed. Gillian Russell and Delia Graff Fara. New York: Routledge: 495-512.

Michael Devitt is Distinguished Professor of Philosophy at the Graduate Center at CUNY. His research interests include the philosophy of linguistics and the philosophy of language. He is the author of Designation (Columbia,1981), Coming to Our Senses (CUP, 1996), Language and Reality (with Kim Sterelny, MIT, 1999), Ignorance of Language (OUP 2006), and the editor (with Richard Hanley) of the Blackwell Guide to the Philosophy of Language (Blackwell, 2006). His most recent book is Putting Metaphysics First (OUP, 2010).

AdDRESS: The Graduate Center, City University of New York, 365 Fifth Ave., New York, NY 10016, USA. E-mail: mdevitt@gc.cuny.edu 